were employed in manufacturing and non-manufacturing work had almost identical rates of abortion, and this relativity was not affected after logistic regression had accounted for differences in age, parity, history of abortion, education, and smoking. Thus there were no important differences between the two groups in these respects.

This study thus provides support for the findings of Clarke and Mason that leatherwork in pregnancy may be associated with an increased risk of stillbirth. ' The excess was entirely in the previous pregnancies, for which our data were complete and, we believe, reliable. In current pregnancies, in which stillbirths were incompletely ascertained, the absence of excess (one observed against 0.95 expected) is based on numbers too small to be interpreted. The difference between the ratio of observed to expected cases in current and previous pregnancies is no more than can be explained by chance. We did not, however, find any convincing evidence of an increase in fetal malformations. The only type of congenital defect on which Clarke and Mason commented were the three cases of trisomy 18 in an estimated 1200 births, or one in 400 . As we had only 346 term pregnancies in leatherworkers and no case of trisomy 18 we are not able to confirm or refute their finding.
There is not necessarily any contradiction in finding a hazard that causes stillbirth and not malformation. A toxic agent acting later in pregnancy even over a short period could kill a fetus, whereas our knowledge of teratology suggests that only an agent acting at the right time in the first trimester might cause a malformation.

The findings of Clarke and Mason and our own suggest that leatherwork may possibly expose women to a fetotoxic agent. We examined the work histories of the eight women in our study whose infants were stillborn; all operated sewing machines, three manufacturing shoes, three bags, and one belts. Five of the eight described exposure to glues (or cements, or both), one to paint, and one to silicone. It seems desirable to investigate the possible fetotoxicity of materials used in the manufacture of leather products.

\section{Reference}

1 Clarke M, Mason ES. Leatherwork: a possible hazard to reproduction. Br Med J 1985;290:1235-7.

(Accepled 14 Februany 1986)

\title{
Remission of symptoms during long term treatment of metastatic pancreatic endocrine tumours with long acting somatostatin analogue
}

\author{
J L C CH'NG，J V ANDERSON，S J WILLIAMS， D H CARR，S R BLOOM
}

\begin{abstract}
Five patients with metastatic pancreatic endocrine tumours injected a long acting somatostatin analogue (SMS 201-995) $50 \mu \mathrm{g}$ subcutaneously every 12 hours and were followed up for three to six months. Treatment aimed at controlling excess secretion of hormone by the tumours thereby bringing symptomatic relief.
\end{abstract}

Four patients showed a significant reduction in tumour related hormone concentrations but in none did values return to normal. All five patients, however, noted definite symptomatic improvement and in one this was dramatic (disappearance of life threatening diarrhoea and correction of metabolic acidosis and hypokalaemia within 48 hours). Mild worsening of symptoms and increasing fasting tumour related hormone concentrations after three to six months of treatment were reversed by doubling the 12 hourly dose. The treatment was well tolerated and had no deleterious effect on fasting blood glucose concentrations.

This somatostatin analogue seems a promising non-invasive treatment for metastatic pancreatic endocrine tumours.

\footnotetext{
Department of Medicine, Royal Postgraduate Medical School, Hammersmith Hospital, London W12 0HS

J L C CH'NG, MB, MRCP, research fellow and honorary registrar

J V ANDERSON, MA, MRCP, research fellow and honorary registrar

$\mathrm{S} J$ WILLIAMS, BSC, research assistant

$S$ R BLOOM, MD, FRCP, professor of endocrinology

Department of Radiology, Royal Postgraduate Medical School, Hammersmith Hospital, London W12 0HS

D H CARR, MD, FRCR, senior lecturer in diagnostic radiology

Correspondence to: Professor Bloom.
}

\section{Introduction}

Pancreatic endocrine tumours (apudomas), being slow growing malignancies, cause morbidity and mortality by virtue of the excess hormones that they secrete. Most patients have metastases at presentation, and treatment is then palliative. In contrast with many other metastatic malignancies, however, years of symptomatic relief may result if the tumour related hormone excess can be controlled. Current methods of treatment are surgical debulking, arterial embolisation of hepatic metastases, and chemotherapy. Native 14 amino acid somatostatin has been shown to have potent antisecretory properties on these tumours. ${ }^{1}$ To be therapeutically useful a long acting and conveniently administered analogue is needed. We report the preliminary results of using such an analogue (SMS 201-995, Sandoz Laboratories, Basle).

\section{Patients and methods}

We studied five patients with metastatic pancreatic endocrine tumours. Two patients had tumours secreting vasoactive intestinal polypeptide (vipomas), two had glucagonomas, and one had a tumour producing growth hormone releasing factor. Four of the patients had relapsed after other forms of treatment, while one declined chemotherapy and invasive forms of treatment.

Before starting treatment with SMS 201-995 we assessed the patient's clinical condition, tumour related hormone concentration, blood glucose concentration, and tumour bulk (by computed tomography; CT). The acute tumour related hormone response to a test dose of 50 $\mu \mathrm{g}$ SMS 201-995 subcutaneously was also determined.

Initial treatment was with $50 \mu \mathrm{g}$ SMS 201-995 given subcutaneously every 12 hours. The patients injected the analogue, using a method similar to insulin injections in diabetics. Full clinical and hormonal evaluation was undertaken every three months. Two patients were followed up for six months and three patients for three months.

Tumour related hormone concentrations were measured by radioimmunoassay. ' 
Clinical and hormonal profiles of patients before and after treatment with SMS 201-995

\begin{tabular}{|c|c|c|c|c|c|c|c|}
\hline \multirow[b]{2}{*}{$\begin{array}{l}\text { Case } \\
\text { No }\end{array}$} & \multirow[b]{2}{*}{$\begin{array}{l}\text { Age and } \\
\text { sex }\end{array}$} & \multirow[b]{2}{*}{ Diagnosis } & \multirow[b]{2}{*}{ Previous treatment } & \multicolumn{2}{|c|}{ Before SMS 201-995 } & \multicolumn{2}{|c|}{ After SMS 201-995* } \\
\hline & & & & Clinical state & $\begin{array}{c}\text { Mean hormone } \\
\text { concentration }(\text { SEM }) \oint\end{array}$ & Clinical state & $\begin{array}{c}\text { Mean hormone } \\
\text { concentration }(\mathrm{SEM}) \oint\end{array}$ \\
\hline 1 & $44 M$ & Vipoma & $\begin{array}{l}\text { Streptozocin and hepatic } \\
\text { arterial embolisation }\end{array}$ & $\begin{array}{l}\text { Severe watery diarrhoea, } \\
\text { hypokalaemia, } \\
\text { dehydration }\end{array}$ & VIP $361(19) \mathrm{pmol} / 1$ & $\begin{array}{l}\text { Diarrhoea stopped, } \\
\text { hypokalaemia and dehydration } \\
\text { corrected. Returned to work }\end{array}$ & VIP $207(25) \mathrm{pmol} / 1 \dagger$ \\
\hline 2 & $57 \mathrm{M}$ & Vipoma & $\begin{array}{l}\text { Hepatic arterial } \\
\text { embolisation and } \\
\text { streptozocin }\end{array}$ & $\begin{array}{l}\text { Watery diarrhoea, } \\
\text { weight loss }\end{array}$ & $\mathrm{VIP} 120(2) \mathrm{pmol} / 1$ & $\begin{array}{l}\text { Diarrhoea stopped, } \\
\text { regained weight }\end{array}$ & VIP 60 (2) pmol/1† \\
\hline 3 & $70 \mathrm{M}$ & Glucagonoma & $\begin{array}{l}\text { None: declined } \\
\text { invasive methods }\end{array}$ & $\begin{array}{l}\text { Severe generalised rash, } \\
\text { hypoproteinaemia, } \\
\text { anaemia }\end{array}$ & Glucagon 458 (3) $\mathrm{pmol} / 1$ & $\begin{array}{l}\text { Rash subsided, hypoproteinaemia } \\
\text { and anaemia improved }\end{array}$ & Glucagon 364 (4) pmol/1 \\
\hline 4 & $66 M$ & Glucagonoma & $\begin{array}{l}\text { Hepatic arterial } \\
\text { embolisation and } \\
\text { streptozocin }\end{array}$ & $\begin{array}{l}\text { Rash on trunk and } \\
\text { buttocks; worsening } \\
\text { diabetic control }\end{array}$ & Glucagon 340 (7) pmol/1 & $\begin{array}{l}\text { Rash subsided, improved } \\
\text { diabetic control }\end{array}$ & Glucagon 332 (7) pmol/1 \\
\hline 5 & $60 \mathrm{~F}$ & $\begin{array}{l}\text { GRF secreting } \\
\text { apudoma }\end{array}$ & $\begin{array}{l}\text { Hepatic arterial } \\
\text { embolisation }\end{array}$ & $\begin{array}{l}\text { Acromegaly, sweating, } \\
\text { tiredness }\end{array}$ & $\begin{array}{l}\mathrm{GRF} 3100 \mathrm{pmol} / \mathrm{l} \\
\mathrm{GH} 24(1) \mathrm{mIU} / \mathrm{l}\end{array}$ & $\begin{array}{l}\text { Inappropriate sweating } \\
\text { stopped }\end{array}$ & $\begin{array}{l}\mathrm{GRF} 1200 \mathrm{pmol} / 1 \ddagger \\
\mathrm{GH} 8(1) \mathrm{mIU} / \mathrm{l} \dagger\end{array}$ \\
\hline
\end{tabular}

\section{Results}

The table summarises the results. The fasting tumour related hormone concentration fell by at least $60 \%$ of basal value after the $50 \mu \mathrm{g}$ test dose in every case. All patients showed definite symptomatic improvement. In case 1 this was dramatic, with disappearance of life threatening diarrhoea and correction of metabolic acidosis and hypokalaemia within $\mathbf{4 8}$ hours of initiating treatment. (This case is reported in detail elsewhere. ${ }^{3}$ ) In the other patients clinical improvement started after two to seven days of treatment.

Significantly lower tumour related hormone concentrations were seen after regular treatment with the analogue in four patients. In none of the patients, however, did the hormone concentrations return to normal. One patient (case 4) showed no change of hormone concentrations despite benefiting clinically.

CT showed possible shrinkage of hepatic metastases in case 1 , no change in tumour bulk in cases 2 to 4 , and a progressive increase in size in case 5 . All patients showed mild symptomatic deterioration or increasing fasting tumour related hormone concentrations after three to six months of treatment. These were effectively reversed by increasing the dose of the analogue to $100 \mu \mathrm{g} 12$ hourly.

No deterioration of fasting blood glucose concentration (mean 6.26 (SEM 0.32) $\mathrm{mmol} / \mathrm{l}(113.0(5 \cdot 8) \mathrm{mg} / 100 \mathrm{ml})$ before treatment) was seen after treatment $(6.30(0.59) \mathrm{mmol} / 1 ; 114.0(10.6) \mathrm{mg} / 100 \mathrm{ml})$. Apart from local skin irritation during and for a few seconds after injection, long term treatment with SMS 201-995 was well tolerated.

\section{Discussion}

This study shows that satisfactory palliation of metastatic pancreatic endocrine tumours can be achieved with SMS 201-995. Our results extend those in two recent case reports of its use in vipomas ${ }^{3+}$ and show that its effectiveness is not confined to tumours secreting vasoactive intestinal polypeptide but applies also to othein APUD cell neoplasms.

Clinical improvement was rapid with the vipomas, but even witis the other tumours response occurred after only one week's treats ment, allowing patients with metastatic tumours to lead normab lives at home. The treatment required minimal time in hospita The improvement in the patients' clinical condition despite the cone tinuing raised hormone concentrations may have occurred because the somatostatin analogue also has a direct effect on the hormone's target organ. This may explain the beneficial effect of the somatoo statin analogue in some cases of diarrhoea not due to abnorma? secretion of vasoactive intestinal polypeptide. ${ }^{5}$

The need to increase the dose after three to six months may be duo to mild desensitisation or to progression of tumour. Tachyphylaxio was not a serious problem in this study.

SMS 201-995 appears promising as a safe, effective, and non invasive treatment for metastatic pancreatic endocrine tumourso

\section{References}

1 Long RG, Barnes AJ, Adrian TE, et al. Suppression of pancreatic endocrine tumour secretion bs long-acting somatostatin analogue. Lancet 1979;ii; 764-7.

2 Blem SR, Long RG. Radiommunoassay of gut regulaton peptides. London: Saunders, 19823 3 Kraenzlin ME, Ch'ng JLC, Wond SM, Carr DH, Bloom SR. Long-term treatment of a vipoms with somatostatin analogue resulting in remission of symptoms and possible shrinkage of metastases. Gustroenterolog 1985:88:185-7.

4 Maton PN, O'Dorisio TM, Howe BA, et al. Effect of a long-acting somatostatin analogutr SMS 201-995) in a patient with pancreatic cholera. N Engl f Med 1985;312:17-21.

5 Williams NS, Cooper JC, Axon ART, King RFGJ, Barker M. Use of a long acting somatostation analogue in controlling life threatening ileostomy diarrheea. Br Med f 1984:289:1027-8.

Accepted 25 Februan 1986 